\title{
LEARNING MANAGEMENT SYSTEMS: A NEW OPPORTUNITY
}

\author{
Audrey Dunne and Tom Butler \\ Business Information Systems, University College Cork, Ireland
}

\begin{abstract}
In an intensely competitive, rapidly evolving, and increasingly knowledgebased IT sector, the ability to learn becomes critical to the success of IT organizations. In today's knowledge economy, a firm's intellectual capital represents the only sustainable source of competitive advantage. This intellectual capital manifests itself, predominantly, in the form of both the individual and the collective competencies of employees within an organization. The knowledge management approach which seeks to facilitate the sharing and integration of knowledge has had limited success, primarily because of its focus on 'knowledge as a resource' rather than on 'learning as a people process'. A strategic 'people-oriented' approach to the management of learning is now emerging in many organizations and this has, in turn, led to the appearance of a new breed of Information Systems (IS) known as 'Learning Management Systems' (LMS). Based on a case study of the implementation of an LMS by a major multinational IT enterprise, this paper proposes an empirically tested framework for 'learning in organizations' and highlights the roles that LMS can play in the continued commercial success of IT organizations.
\end{abstract}

Key words: Learning Management, Theory Building, IS Research, Knowledge, Learning in Organizations, Organizational Learning.

\section{INTRODUCTION}

The critical role that organizational learning plays in IT organizations has long been noted; indeed Ray Stata, the founder and former CEO of Analog Devices Inc., argued that it was the key to the management of innovation (Stata, 1989). Accordingly, IT organizations such as Siemens and Analog Devices Inc. have leveraged the power of Knowledge Management Systems 
(KMS) to this end; however, the limitations of such systems has been noted (Butler, 2003).

A new breed of Information Systems (IS) known as Learning Management Systems (LMS) are evolving to enable learning in organizations (Brennan, Funke and Andersen, 2001; Hall, 2001; Nichani, 2001; Greenberg, 2002). The need for such systems is reflected by the fact that IT organizations such as Cisco Systems, VERITAS Software, Alcatel and Xilinx are employing learning management to foster and manage learning within their organizations ${ }^{1}$. In essence, LMS replace isolated and fragmented learning programs with a systematic means of assessing and raising competency and performance levels throughout the organization, by offering a strategic solution for planning, delivering and managing all learning events including both online and classroom-based learning (Greenberg, 2002). The present focus on 'Learning Management' has been led primarily by industry practitioners and industry vendors and there is little empirical research in this area. Hence, the principal objective of this study is to deepen the IS field's understanding of the contribution of these new systems to learning within organizations.

The remainder of this paper is structured as follows: The next section considers the motivation for the study; following this, the research approach is outlined. The penultimate section details the overall findings of the study and presents an empirically tested framework for learning in organizations that incorporates the new phenomenon of LMS. The paper then discusses some of the opportunities and challenges presented to us by LMS and offers concluding suggestions for further research in the area.

\section{MOTIVATION FOR THE STUDY}

\subsection{The Importance of Learning in Organizations}

Many definitions of 'organizational learning' have been articulated. Perhaps, the most succinct of these is that of Fiol and Lyles (1985, p.803) who state that "Organizational Learning means the process of improving actions through better knowledge and understanding." The importance of facilitating and managing learning within organizations is well accepted. Zuboff (1988), for example, argues that learning, integration and communication are critical to leveraging employee knowledge; accordingly,

\footnotetext{
${ }^{1}$ http://www.saba.com/english/customers/index.htm
} 
she maintains that managers must switch from being drivers of people to being drivers of learning. Harvey and Denton (1999) identify several antecedents which help to explain the rise to prominence of organizational learning, viz.

- The shift in the relative importance of factors of production away from capital towards labour, particularly in the case of knowledge workers.

- The ever more rapid pace of change in the business environment.

- Wide acceptance of knowledge as a prime source of competitive advantage.

- The greater demands being placed on all businesses by customers.

- Increasing dissatisfaction among managers and employees with the traditional 'command control' management paradigm.

- The intensely competitive nature of global business.

\subsection{Deficiencies in the Knowledge Management Approach}

During the 1990s, there was a major shift in focus from organizational learning to knowledge management, in both applied and theoretical contexts (Easterby-Smith, Crossan and Nicolini, 2000; Scarbrough and Swan, 2001; Alvesson and Kärreman, 2001). Knowledge Management Systems (KMS) seek to facilitate the sharing and integration of knowledge (Alavi and Leidner, 1999; Chait, 1999; Garavelli, Gorgoglione and Scozzi, 2002). However, these systems have had limited success (Shultz and Boland, 2000) with reported failure rates of over $80 \%$ (Storey and Barnett 2000). This is because many of them are still, for the most part, used to support data and information processing, rather than knowledge management (Borghoff and Pareschi, 1999; Sutton, 2001; Hendricks, 2001; Garavelli et al., 2002; Butler, 2003) and also because many implementations neglect the social, cultural and motivational issues that are critical to their success (McDermott, 1999; Schultze and Boland, 2000; Huber, 2001). Indeed knowledge management may be more of a new 'fashion' or 'fad' that has been embraced by the IS field (Swan, Scarborough and Preston, 1999; Butler, 2000; Galliers and Newell, 2001) and its popularity may be heightened by glossing over the complex and intangible aspects of human behavior (Scarborough and Swan, 2001).

\subsection{New Potential Offered by Learning Management Systems}

It is perhaps time to admit that neither the 'learning organization' concept, which is people oriented and focuses on learning as a process, nor 
the knowledge management concept, which focuses on knowledge as a resource, can stand alone. These concepts compliment each other, in that the learning process is of no value without an outcome, while knowledge is too intangible, dynamic and contextual to allow it to be managed as a tangible resource (Rowley, 2001). She emphasizes that successful knowledge management needs to couple a concern for systems with an awareness of how organizations learn. Researchers believe that what is needed is to better manage the flow of information through and around the "bottlenecks" of personal attention and learning capacity (Wagner, 2000; Brennan et al., 2001) and to design systems where technology is in service to and supports diverse learners and diverse learning contexts (McCombs, 2000). In response to this need, another breed of systems known as Learning Management Systems (LMS) have evolved and many firms are now using this technology to take a new approach to learning within organizations. This new 'learning management' approach has been led primarily by a number of practitioners and IT vendors and there is a dearth of empirical research in this area. Therefore, an important challenge for the IS field is to better understand LMS and to examine the roles and relationships of these new systems within organizations.

\section{RESEARCH APPROACH}

This study's primary objective is to examine how LMS may be utilized in an organizational context to facilitate and manage organizational learning. A conceptual model and related research framework is employed to guide the conduct of the investigation. A 'single' case study approach was selected for three key reasons. Firstly, the case study research method is particularly suited to IS research (Benbasat, Goldstein and Mead, 1987; Myers, 1997), since the objective is the study of IS in organizations and "interest has shifted to organizational rather than technical issues" (Benbasat et al., 1987). Case research, with its emphasis on understanding empirical data in natural settings (Eisenhardt, 1989) is an appropriate method for studying IS issues and practices. Furthermore, Benbasat et al. (1987) maintain that IS researchers should learn and theorize primarily from studying systems in practice, as much IS research trails behind practitioners' knowledge. Indeed, this is the case with respect to the availability of empirical research on LMS.

Secondly, the objective of the research is exploratory in nature and the single case study is considered to be a potentially rich and valuable source of data and is well suited to exploring relationships between variables in their given context, as required by exploratory research (Pettigrew, 1985; Benbasat et al., 1987; Yin, 1994; Stake, 1994). 
Thirdly, the main argument against single cases has been answered by Lee (1989). He points out that single cases differ from multiple cases only in their degree of generalizability and in this sense, the 'lessons' learned from our case have been formulated as postulates, with specific view to their validity being confirmed, or otherwise, in future research.

\subsection{Conceptual Model and Research Framework}

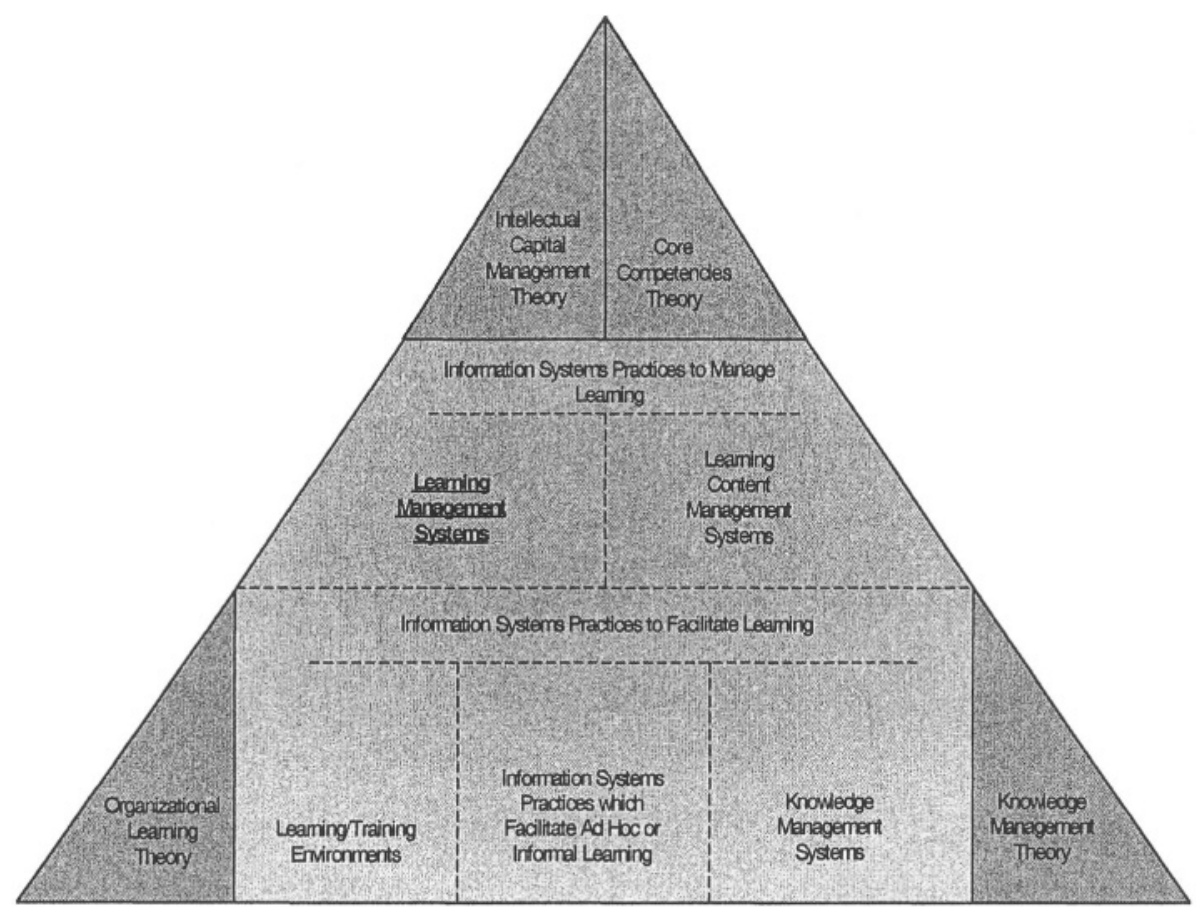

Pecple Oriented, Human Relations/Community Focus

Resource Orlented, Knowledge Distribution/Cognition Focus

Figure 1. Learning in Organizations: Conceptual Model

The conceptual model and related research framework for the study were drawn from the literature to help guide the conduct of the study. The conceptual model depicted in Figure 1 establishes the boundaries of this research study. The relevant theoretical influences are shown on the periphery of the model and their positioning on the $\mathrm{x}$-axis indicates the degree to which they are oriented towards a people or community focus at one end of the continuum, or a resource or knowledge distribution focus on the other end of the continuum. These theories are: (1) organizational learning theory; (2) competence theory; (3) intellectual capital theory; and 
(4) knowledge management/knowledge transfer theory. Organizational learning theory is primarily people oriented; while knowledge management theory is primarily resource oriented; however intellectual capital theory and competency theory are both people and resource focused. The major categories of IS which support learning in organizations are all represented at the core of the model and are separated only by dotted lines, indicating that there are a lot of interconnections and indeed, intersections between them. These categories are: (1) Learning Management Systems; (2) Learning Content Management Systems; (3) Learning/Training environments; (4) Knowledge Management Systems; and (5) Information Systems that facilitate ad hoc and informal learning. It is proposed that learning and training environments and LMS tend to be people oriented, while KMS and LCMS concentrate more on knowledge resources and learning content. Organizational systems which facilitate ad hoc or informal learning vary considerably in their attention to people issues versus resource issues. Finally, the model distinguishes between IS that is used by management to manage learning within organizations and IS that facilitate learning and that are experienced at the cold-face of everyday life in organizations.

The research framework for this study was generated from a review of extant theory and research and depicts the topology of the key theories and categories of IS that underpin learning in organizations (see Figure 2). The framework illustrates that the theories have helped mould and shape the way that IS are used to support learning. Links drawn between the theories indicates that they have had an influencing role on each other. The IS category of LMS is highlighted within the framework to emphasize that this is the area of focus for the study. Links drawn from one systems category to another signifies potential interrelationships between them. The main premises which underpin this framework are:

- LMS can play a critical role in organizations by facilitating the "people centered' management of learning.

- IS that facilitate and promote either formal or informal learning (or a combination of both) in an organization, possess interrelationships with each other; furthermore, the roles played by these systems is greater than the sum of their parts.

- Key theories of learning within an organizational context have influenced the way in which IS are used to facilitate and promote learning in organizations. 


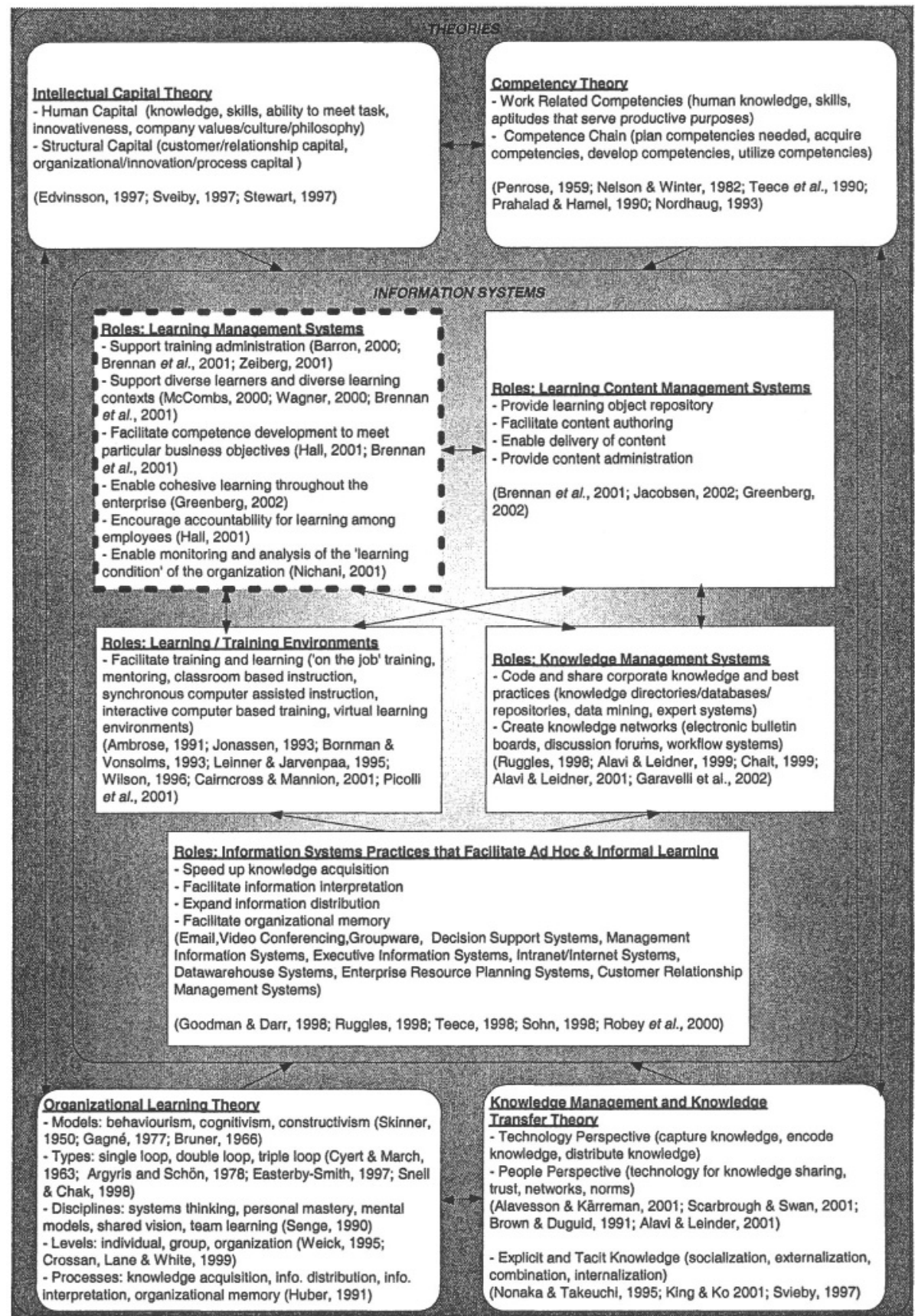

\section{Figure 2. Learning in Organizations: Research Framework}

Within the context of this framework, three research questions were formulated to help attain this study's research objective: 
Research Question 1: What are the roles of the Learning Management System in managing learning within the organization?

Research Question 2: What is the relationship between the Learning Management System and the other Information Systems that support learning in the organization?

Research Question 3: What theories have influenced how the organization uses its Learning Management System to manage learning within the organization?

\subsection{Implemention of the Research Method}

The organization chosen for study was a major US multinational supplier of data storage solutions to the IT market that had recently implemented an LMS as part of its learning management strategy. For reasons of confidentiality, this organization cannot be identified and will be referred to as CEM Corporation. The LMS in use at CEM was complex and multifaceted system; hence, it was necessary to conduct several exploratory interviews with the subject matter expert. Five such site visits occurred over a six month period and each meeting lasted between one and one and a half hours. This type of elite interviewing (Marshall and Rossman, 1989) is sometimes necessary to investigate little understood phenomena. In one of these sessions, a detailed demonstration of how the system operates was provided by the Training Manager. A second demonstration of the system was subsequently obtained from a Training Specialist within CEM Corporation. This provided the researchers an understanding of the system's capabilities and insights into how the system is used on a day to day basis. The Human Resources Manager was also interviewed at this stage. Subsequently, the researcher carried out eight semi-structured interviews. Appendix A provides an outline of the interview guide as well as the profiles of the interviewees.

\section{LMS: TOWARDS A BETTER UNDERSTANDING}

In February 2001, CEM Corporation deployed a Learning Management System known as Saba Learning Enterprise ${ }^{\mathrm{TM}}$ to employees across the entire enterprise, as well as to CEM customers and business partners. The business drivers for deploying this enterprise learning solution were:

- Decrease time-to-competency. 
- Develop and manage skill sets for all employees.

- Leverage global, repeatable and predictable curriculum.

- Integrate competency assessments to development plans.

- Accelerate the transfer of knowledge to employees, partners, and customers.

- Provide a single learning interface for all internal and external users.

Currently, this corporate-based system is used by training managers primarily within the manufacturing and customer services organizations of CEM Corporation to deliver and track both technical and business training programs. Training administrators within these divisions use the system to administer and manage training courses, for example - they publish and manage learning content; they manage a catalogue of courses; and they create reports on learning activities. The system is also used by other training managers to formulate additional types of training and learning across the entire corporation, including individual personal development programs and management training.

Many employees within CEM Corporation are using the LMS to manage their own learning processes, for example - they use the system to enrol in classroom courses, to search for learning material, to engage in online learning activities, and to look at what development options are suitable for their role within the organization. Furthermore, the LMS facilitates a competency assessment process which enables employees to identify gaps or shortfalls in their competency levels with respect to a competency model defined for their own specific job role. Both business managers and technical managers within CEM Corporation use the system to manage the learning processes of their employees, for example - they examine the status of learning activities for their employees; they assign learning initiatives to be carried out by their employees; and they generate reports on these learning activities.

\subsection{LMS: Location in the Enterprise Learning Solution}

Figure 3 illustrates the multifaceted nature of CEM's Enterprise Learning Solution. Much of the learning material is created and maintained by CEM employees using a variety of products. Content is stored on CEM's own storage repository, on site. In addition, courseware that is created and maintained directly by third parties is stored offsite in the storage repository of the third party organization. Courseware is provided to CEM Corporation by a number of third party learning content suppliers.

The LMS has the capability of managing and tracking both offline activities (e.g. books, 'on the job' training, mentoring, classroom training) and online activities (e.g. video and audio, rich media, web casts, web-based 
training, virtual classroom training). In the case of online activities, learning content may be accessed and delivered through the LMS either from CEM's repository or from the third party's storage repository. Certain testing is built into the learning content itself, but additional pre-training-testing and post-training-testing may be invoked and this is currently provided by another third party product. While much of the required reporting is provided by the LMS, administrators also use third party software to generate more sophisticated reports.

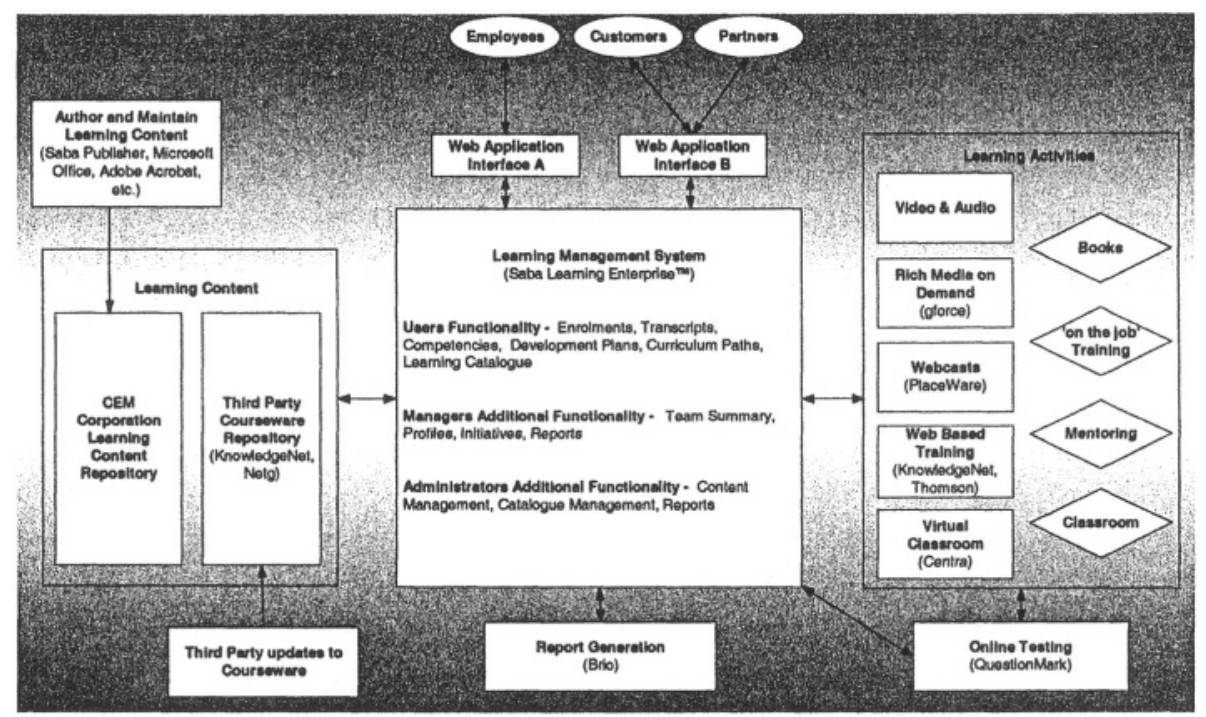

Figure 3. CEM Corporation: Enterprise Learning Solution Components

\subsection{LMS: Key Roles}

The research framework was tested using the empirical findings and was modified accordingly, see Figure 4. The findings indicate that to some extent, the LMS within this organization fulfills all of the roles suggested in the research framework. Furthermore, the research identified a number of additional roles that were not suggested in the framework, but that are being performed by the LMS. One of the primary roles of the LMS within CEM Corporation to date has been its assistance to Training Managers in supporting the administration of training ${ }^{2}$ across such a large organization with a variety of training needs. This has had a consequential effect of increasing the productivity of training.

${ }^{2}$ Bold text within this section indicates that this is a role fulfilled by the Learning

Management System. 


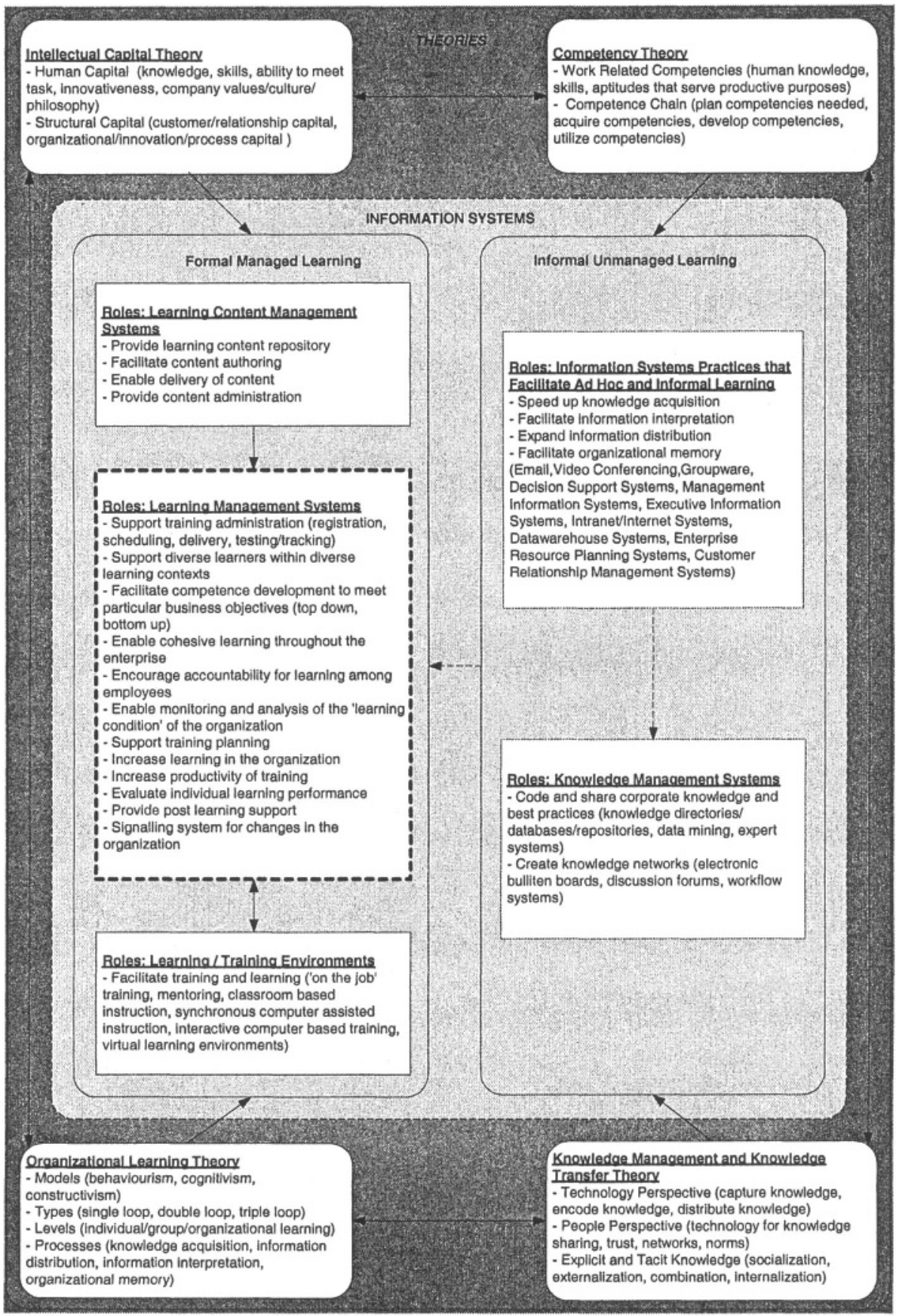

Figure 4. Learning in Organizations: Modified Framework and Summary of Findings

From a learner's perspective, the principal role played by the LMS is that it provides a central repository for a range of learning material in a 
structured way which enables the system to support a diverse body of learners within diverse learning contexts. This leads to the most critical role of all, which is that it increases the use of training and hence, increases learning in the organization. Also from the perspective of the learner, two other significant and emerging roles of the LMS were highlighted, namely; the provision of post learning support; and the role of the LMS as a signaling system for changes in the organization, when new training is made available on the system.

Although role-based competency models have been set up on the LMS for many employees within the organization, CEM Corporation is still in the early stages of constructing workable competency models for all employees. Difficulties were highlighted in relation to certain technical positions which primarily involved specialist skills. Challenges were also emphasized in relation to positions involving varying requirements for depth and breath of knowledge of a particular skill. The extent of investment in time and effort in drawing up these 'technical role-based competency models' is such that the effort is justified only if it is driven by the local business in the context of local business needs. Furthermore, it must be noted that CEM Corporation is also in the early stages of mobilizing the competency assessment process, even in relation to job roles for which there is a standard competency model available. However, in some parts of the organization, employees have already begun to engage with the LMS to carry out competency assessments against the standard competency model related to their own particular role.Subsequently, and usually in consultation with their managers, employees have reviewed the learning options available and devised development plans for acquiring the competencies in which they are deficient. Although this functionality is still being rolled out across CEM Corporation, it is clear that the LMS is beginning to fulfill the vital role of facilitating competence development to meet particular business objectives, through a dual approach to learning management (i.e. top down and bottom up). From a top down perspective, Training Managers within CEM Corporation have already started to use the LMS to automate the 'training needs analysis' process which will assist them in the identification of training needs and will support training planning. From a bottom up perspective, CEM Corporation is encouraging employees to self manage their own learning using LMS and this has the added benefit of encouraging accountability for learning among employees.

The use of competency models for assessing and developing competencies forms the basis of a number of other key roles of the LMS which are beginning to emerge. Through standardizing role-based competency requirements and development options, the LMS is already enabling more consistent and cohesive learning throughout the enterprise. 
Assessing employees against the standard competency model for their particular role enables the monitoring and analysis of the 'learning condition' of the organization. Furthermore, by reviewing progress between one competency assessment and the next, evaluation of individual learning performance for any employee is facilitated. This may then form part of the individual's overall performance evaluation. The research findings highlighted the sensitivity that surrounds performance assessments overall and stressed the need for a significant human element in assessing performance. In particular, the need for joint agreement between an employee and their immediate superior on future development plans was emphasized.

\subsection{LMS: Relationships to and Influence of Theories}

The relationships between the LMS and the other IS that support learning within CEM Corporation were investigated within the context of the research framework. In addition, the impact of leading theories was considered in relation to how they had influenced CEM Corporation in its use of the LMS to manage learning. As can be seen in Figure 4, it was found that while the LMS is fed by a direct link to the LCMS (i.e. The LMS remotely accesses learning content on the LCMS), and has a strong two way relationship with 'learning/training environments', it has only a tenuous link to other Information Systems that support ad hoc or informal learning, including KMS. The link from these systems consists primarily of a need which they generate for formal learning and training programs. The content for this training will often stem from the system itself and the type of environment used will, more than likely, be decided by the nature of the system in question. KMS often store information on problems and solutions relating to other systems that support informal learning and so there is a tentative link between these groups of systems. KMS, while supporting knowledge management in a formal way, only support informal unmanaged learning, as the learning is not delivered in a structured way, nor is it measured or validated. The findings also indicate that the LMS, together with the LCMS and the learning/training environments, all contribute to process of formal managed learning within the organization. On the other hand, IS which facilitate ad hoc or uncontrolled learning together with KMS, support informal unmanaged learning within the organization. 
The study found that all of the theories ${ }^{3}$ reviewed have influenced CEM Corporation in its use of The LMS. Organizational learning theory, however, has had a greater effect on what types of learning content and on which types of learning environments that CEM Corporation uses to facilitate various forms of learning within the organization, than on how the LMS is employed to manage that learning. Intellectual capital theory played a critical role in the decision to implement an LMS initially and continues to underpin the mission of the initiative which is to maximize intellectual capital within the organization. Competence theory is influencing CEM Corporation on an ongoing basis, in particular, its use of the LMS to manage competency levels across the organization. Knowledge management and knowledge transfer theory has also played a key role in how CEM Corporation uses the LMS to manage all forms of 'knowledge learning'.

The size and complexity of CEM Corporation made it very difficult to establish if the organization as a whole was more influenced by organizational learning theory, and thus more oriented towards a people or community focus, or if it was more influenced by knowledge management theory, and thus more oriented towards a resource or knowledge distribution focus. When questioned about this, the responses of individual interviewees varied considerably and this in itself would indicate that CEM Corporation holds a pluralist approach, and is thus more resource oriented in certain parts of the organization, while it is more people focused in other areas.

\section{LMS: OPPORTUNITIES, CHALLENGES AND CONCLUSIONS}

This study illustrates that the introduction of an LMS can replace the isolated and fragmented learning programs in an organization with a systematic means of assessing and raising competency and performance levels throughout the organization (see Geenberg, 2002). For IT organizations, such as CEM Corporation, who operate in a dynamic environment where product sophistication and complexity grows with each generation, and where customer and product support is a competitive advantage, LMS offer a strategic solutions for planning, delivering and managing all learning events, including both online and classroom-based learning. The research findings show that an LMS can play a vital role in increasing learning within the organization. This may be achieved in part by

3 Theories reviewed: organizational learning theory, intellectual capital theory, competence theory, knowledge management/knowledge transfer theory. 
increasing the control and management of employee competency levels, but equally importantly, it may also be achieved by empowering employees to be creative in managing their own competency development and learning. The challenge for management is to increase their influence and control over training and learning within the organization, while at the same time encouraging employees to take ownership for their own levels of knowledge and to be committed to ongoing self development.

As outlined earlier, learning is a complex undertaking, especially in organizational contexts. Managing learning and measuring learning outcomes is difficult, but is made even more problematic within complex learning domains, such as those that exist in IT organizations such as CEM Corporation. It is unlikely that an LMS will manage all of the learning in an organization in a 'truly scientific way', though it will assist greatly in managing the diverse and extensive array of learning contexts and learning process which must be supported. Its strengths lie in the new approach and attitude that it will encourage and inspire in the hearts and minds of individuals within the organization, as it enables learning that is more visible within the organization, more structured and more accessible. This stimulation of the hearts and minds is a major contributing factor to learning and is known as 'emotional quotient' (Goleman, 1996). According to Nelson and Winter (1982), an organization's practiced routines determine what it is capable of doing. They propose that the routinization of an activity within an organization constitutes the most important form of storage of the organization's specific operational knowledge. As an LMS facilitates learning structures and learning processes, it thus encourages the routinization of learning within the organization and promotes a learning culture in which formal learning and training are further integrated into everyday work practices.

CEM Corporation still has a way to go to fully exploit the benefits offered by the LMS. Firstly, not all formal training is currently being tracked and managed through the Learning Management System. One of the key organizations within CEM Corporation does not yet use the LMS to manage and track its own technical training. Secondly, role-based competency models have not been drawn up for all roles and this process may be hindered as the construction of competency models for some of the more specialist technical roles may be time consuming and problematic. Even where competency models are available within CEM Corporation, many employees, and indeed managers, have not yet engaged with the competency assessment process. These competency assessments will be critical in establishing if positive learning outcomes have been achieved and will demonstrate if the organization is obtaining a return on its investment in implementing an LMS. 
Argyris and Schön $(1978,1996)$ describe organizational deuterolearning learning as " a critically important kind of organizational double-loop learning...through which the members of an organization may discover and modify the learning system that conditions prevailing patterns of organizational inquiry." They equate this to Bateson's (1972) description of second order learning or 'learning how to learn'. It is clear that the implementation and utilization of an LMS represents an attempt to fundamentally change how learning is happening in an organization and signifies a concerted effort to achieve deuterolearning. An LMS offers exciting new opportunities to both employees and management in relation to 'learning how to learn'.

\subsection{LMS: Research directions}

This paper introduces a framework for 'learning in organizations' which incorporates a role for Learning Management Systems (LMS). Researchers maintain that a young field such as IS requires "pre-theory" frameworks to guide research activities while enroute to theory development (Bariff and Ginzberg, 1982; Teng and Galetta, 1991). Crossan, Lane and White (1999) point out that a framework defines the research landscape and directs theory building. The relationships among the framework elements proposed in this paper are described at a high level, however further theory development will expand and deepen these connections and will enable the development of testable hypotheses. Bakos and Treacy (1986) believe that as an area matures, there is an increasing need to move beyond frameworks toward explanatory models of the underlying phenomena. In this way, it becomes possible to build a cumulative tradition and to make normative statements which will guide managerial actions. Hence, a suitable avenue for further research would be to test this study's findings on other similar organizations.

This study supports the contention that learning management methods and tools are well suited to compensate for the deficiencies of current knowledge management techniques (see Hall, 2001; Brennan et al., 2001). Furthermore, new Learning Content Management Systems may be used to store knowledge or course components at object level in relational databases; and are likely to be the closest application yet to bridging knowledge management and learning management. This view is supported by Aldrich (2001), who maintains that using knowledge chunks as the building blocks for electronic learning promotes the convergence of KMS and electronic LMS, in addition to enabling just-in-time-learning.

In its examination of one 'problem-solution oriented' KMS, this study illustrates that there is a potential opportunity for attaching learning activities or specific learning material to knowledge objects within a KMS. Similarly, 
the findings indicate that there are benefits to be gained by using a KMS to review selected problems and solutions relating to a particular topic area, as supplementary learning material at the end of a learning program. Thus, another interesting area for future research would be to investigate the feasibility and potential advantages of merging Learning Management Systems and practices with Knowledge Management Systems and practices, resulting in an integrated holistic solution to organizational requirements for learning and knowledge management $-\mathrm{a}$ 'Knowledge \& Learning Management Systems' or 'KLMS'.

\section{REFERENCES}

Alavi, M. and Leidner, D. "Knowledge Management Systems: Issues, Challenges and Benefits," In Communications of the Association of Information Systems, Volume 1, Issue 2, 1999.

Alavi, M. and Leidner, D. "Review: Knowledge Management and Knowledge Management Systems: Conceptual Foundations and Research Issues," MIS Quarterly (25:1), 2001, pp. 107-136.

Aldrich, C. "Can LMSs Survive the Sophisticated buyer?" In Learning Circuits, American Society for Training and Development, http://www.learningcircuits.org/2001/nov2001/ ttools.html,2001

Alvesson, M. and Kärreman, D. "Odd Couple: Making Sense of the Curious Concept of Knowledge Management," Journal of Management Studies (38:7), 2001, pp. 995-1018.

Ambrose, D.W. "The Effects of Hypermedia on Learning: A Literature Review." Educational Technology, December 1991, pp.51-55.

Argyris, C. and Schön, D.A. Organizational Learning, Reading, Massachusetts: AddisonWesley, 1978.

Argyris, C. and Schön, D.A. Organizational Learning II: Theory, Method and Practice, Reading, Massachusetts: Addison-Wesley, 1996.

Bakos, J.Y. and Treacy, M.E. "Information Technology and Corporate Strategy: A Research Perspective,” MIS Quarterly (10:2), 1986, pp. 107-119.

Bariff, M.L and Ginzberg, M.J "MIS and Behavioural Sciences: Research Patterns and Prescriptions," Data Base, Fall, 1982, pp. 19-26.

Barron, T. "The LMS Guess," In Learning Circuits, American Society for Training and Development, http://www.learningcircuits.org/apr2000/barron.html, 2000.

Bateson, G. Steps to an Ecology of Mind, San Francisco: Chandler, 1972.

Benbasat, I., Goldstein, D.K. and Mead, M. "The Case Research Strategy in Studies of Information Systems," MIS Quarterly (11:3), 1987, pp. 369-386.

Borghoff, U.M. and Pareschi, R. Information Technology for Knowledge Management, Heidelberg: Springer-Verlag, 1999.

Bornman, H. and Vonsolms S.H. "Hypermedia, Multimedia and Hypertext: Definitions and Overview," Electronic Library 11(4-5), 1993, pp. 259-268.

Brennan, M., Funke, S. and Andersen, C. "The Learning Content Management System: A New eLearning Market Segment Emerges," An IDC White Paper, http://www.lcmscouncil.org/resources.html, 2001. 
Brown, J. S. and Duguid, P. "Organizational Learning and Communities of Practice: Toward a Unified View of Working, Learning, and Innovation," Organization Science (2:1), 1991, pp. 40-57.

Bruner, J. Toward a Theory of Instruction, Cambridge, Massachusetts: Harvard University Press, 1966.

Butler, T. "From Data to Knowledge and Back Again: Understanding the Limitations of KMS," Knowledge and Process Management: The Journal of Corporate Transformation, Vol. 10, No. 4, 2003, pp. 144-155.

Cairncross, S. and Mannion M. "Interactive Multimedia and Learning," Innovations in Education and Teaching International 38(2), 2001, pp. 156-164.

Chait, L.P. "Creating a Successful Knowledge Management System," Journal of Business Strategy (20:2), 1999, pp. 23-26.

Crossan, M., Lane, $\mathrm{H}$ and White, R. "An Organizational Learning Framework: From Intuition to Institution," Academy of Management Review (24:3), 1999, pp. 522-537.

Cyert, R.M. and March, J.G. A Behavioral Theory of the Firm, Englewood Cliffs, NJ: Prentice Hall, 1963.

Easterby-Smith, M. "Disciplines of the Learning Organisation: Contributions and Critiques," Human Relations (50:9), 1997, pp. 1085-113.

Easterby-Smith, M., Crossan, M. and Nicolini D. "Organizational Learning: Debates Past, Present and Future," Journal of Management Studies (37:6), 2000, pp. 783-796.

Edvinsson, L. and Malone, M.S. "Intellectual Capital. London, HarperCollins," $e$ LearningHub.com,

http://www.elearninghub.com/articles/learning_management_system.html, 1997.

Eisenhardt, K.M. "Building Theories from Case Study Research," Academy of Management Review (14:4), 1989, pp. 532-550.

Fiol, C. M. and M. A. Lyles "Organizational Learning," Academy of Management Review 10(4), 1985, pp. 284-295.

Gagné, R. The Conditions of Learning, Fourth Edition, London: Holt, Rinehart and Winston, 1977.

Galliers, R. and Newell S. "Back to the Future: From Knowledge Management to Data Management," In Global Co-Operation in the New Millennium, $9^{\text {th }}$ European Conference on Information Systems, Bled, Slovenia, June 27-29, 2001, pp. 609-615.

Garavelli, A.C., Gorgoglione, M. and Scozzi, B. "Managing Knowledge Transfer by Knowledge Technologies," Technovation (22), 2002, pp. 269-279.

Goleman, D. Emotional Intelligence, London: Bloomsbury Publishing, 1996.

Goodman, P. and Darr E. "Computer-Aided Systems and Communities: Mechanisms for Organizational Learning in Distributed Environments," MIS Quarterly 22(4), 1998, pp. 417-440.

Greenberg, L. "LMS and LCMS: What's the Difference?" In Learning Circuits, American Society for Training and Development, http://www.learningcircuits.org/2002/dec2002/ greenberg.htm, 2002.

Hall, B. Learning Management Systems 2001, California: brandon-hall.com, 2001.

Harvey, C. and Denton, J. "To come of Age: Antecedents of Organizational Learning," Journal of Management Studies (37:7), 1999, pp. 897-918.

Hendriks, P.H. "Many Rivers to cross: from ICT to Knowledge Management Systems," Journal of Information Technology (16:2), 2001, pp. 57-72.

Huber, G. P. "Organizational Learning: The Contributing Processes and the Literatures," Organization Science (2:1), 1991, pp. 88-115. 
Huber, G.P. "Transfer of Knowledge in Knowledge Management Systems: Unexplored Issues and Suggestions," European Journal of Information Systems (10:2), 2001, pp. 72-79.

Jacobsen, P. "LMS vs. LCMS," e-learning magazine, Advanstar communications, http://www.elearningmag.com/elearning/article/articleDetail.jsp?id=21264, 2002.

Jonassen, D.H. and Grabowski, B.L. Handbook of Individual Differences, Learning, and Instruction, New Jersey: Lawrence Erlbaum Associates, 1993.

King, W.R. and Ko, D.G. "Evaluating Knowledge Management and The Learning Organization: An Information/Knowledge Value Chain Approach," In Communications of the Association for Information Systems, Volume 5, Article 14, 2001.

Lee, A.S. "A Scientific Methodology for Case Studies," MIS Quarterly (13:1), 1989, pp. 3350.

Leidner, D. E. and Jarvenpaa, S.L. "The Use of Information Technology to Enhance Management School Education, A theoretical View," MIS Quarterly (19:3), 1995, pp. 265-291.

Marshall, C. and Rossman B.G. Designing Qualitative Research, California, Sage, 1989.

McCombs, B.L. "Assessing the Role of Educational Technology in the Teaching and Learning Process: A Learner Centered Perspective," In The Secretary's Conference on Educational Technology, US Department of Education, http://www.ed.gov/Technology/ techconf/2000/mccombs_paper.html, 2000.

McDermott, R. "Why Information Technology Inspired, but Cannot Deliver Knowledge Management," California Management Review (41:4), 1999, pp. 103-117.

Myers, M.D. "Qualitative Research on Information Systems," MIS Quarterly (21:2), 1997, pp. 221-242.

Nelson R.S. and Winter, S.G. An Evolutionary Theory of Economic Change, Cambridge, Massachusetts: Harvard University Press, 1982.

Nichani, M. "LCM S = LMS + CMS [RLOs]," elearningpost, http://www.elearningpost.com/ features/archives/001022.asp, 2001.

Nonaka, I. and Takeuchi, H. The knowledge creating company, Oxford, England: Oxford University Press, 1995.

Nordhaug, O. Human Capital in Organizations, Scandinavia: University Press, 1994.

Penrose, E. The Theory of Growth of the Firm, London: Basil Blackwell, 1959.

Pettigrew, A.M. "Contextualism Research and the Study of Organizational Change Process," In E. Mumford, H. Fitzgerald, H. Klein and A. Wood-Harper (Eds.) Research Methods in Information Systems, Holland: Elsevier, 1985.

Picolli, G., Ahmad R. and Ives B. "Web-based Virtual Learning Environments: A Research Framework and a Preliminary Assessment of Effectiveness in Basic IT Skills Training," MIS Quarterly 25(4), 2001, pp. 401-426.

Prahalad, K. and Hamel, G. "The Core Competence of the Corporation," Harvard Business Review (68:3), 1990, pp. 79-91.

Robey, D., Boudreau M.C. and Rose G.M. "Information Technology and Organizational Learning; A Review and Assessment of Research," Accounting Management and Information Technologies 10, 2000, pp. 125-155.

Rowley, J. "Knowledge Management in pursuit of learning: the Learning with Knowledge Cycle," Journal of Information Science (27:4), 2001, pp. 227-237.

Ruggles, R. "The State of the Notion: Knowledge Management in Practice," California Management Review 40(3), 1998, pp. 80-89.

Scarbrough, H. and Swan, J. "Explaining the Diffusion of Knowledge Management: The Role of Fashion," British Journal of Management (12), 2001, pp. 3-12. 
Schultze, U. and Boland, R.J. "Knowledge Management Technology and the Reproduction of Knowledge Work Practices," Journal of Strategic Information Systems (9:2-3), 2000, pp. 193-212.

Senge, P. M. The Fifth Discipline: The Art and Practice of The Learning Organization, New York: Doubleday, 1990.

Skinner, B.F. "Are theories of learning necessary?" Psychological Review (57), 1950, pp. 193-216.

Snell, R. and Chak A.M. "The Learning Organization: Learning and Empowerment for Whom?" Management Learning (29:3), 1998, pp. 337-364.

Sohn, C. "How Information Systems Provide Competitive Advantage: An Organizational Learning Perspective," In Americas Conference on Information Systems, 1998.

Stake, R.E. "Case Studies," In N.K. Denzin and Y.S. Lincoln (Eds.) Handbook of Qualitative Research, California: Sage Publications, 1994.

Stata, R. "Organizational Learning - The Key to Management Innovation," Sloan Management Review (30:3), 1989, pp. 63-74.

Stewart, T. Intellectual Capital, London: Nicholas Brealey, 1997.

Storey, J and Barnett E. "Knowledge Management Initiatives: Learning from Failure," Journal of Knowledge Management, 4, 2000, pp. 145-156.

Sutton, D.C. "What is Knowledge and can it be managed?" European Journal of Information Systems (10:2), 2001, pp. 80-88.

Sveiby, K.E. The New Organizational Wealth: Managing and Measuring Knowledge Based Assets, San Francisco: Berrett-Koehler, 1997.

Teece, D. "Capturing Value from Knowledge Assets: The New Economy, Markets for Know-How and Intangible Assets," California Management Review 40(3), 1998, pp. 5579.

Teece, D., Pisano, J. and Shuen, A. "Firm Capabilities, Resources and the concept of Strategy," Working Paper No. 90-8. CA, University of California at Berkley, 1990.

Teng J.T.C and Galletta, D.F. "MIS Research Directions: A Survey of Researcher's Views," Data Base Winter/Spring, 1991, pp. 53-62.

Wagner, E.D. "E-Learning: Where Cognitive Strategies, Knowledge Management, and Information Technology converge," In Learning without Limits, Volume 3, Informania Inc, California, http://www.learnativity.com/download/LwoL3.pdf, 2000.

Weick, K.E. Sensemaking in Organizations. Thousand Oaks, CA: Sage, 1995.

Wilson, B.G. Constructivist Learning Environments: Case Studies in Instructional Design. Englewood Cliffs, NJ: Educational Technology Publications, 1996.

Yin, R.K. Case Study Research, Design and Methods, Second Edition, Newbury Park: Sage, 1994.

Zeiberg, C. "Ten steps to Successfully Selecting a Learning Management System," In L. Kent, M. Flanagan and C. Hedrick (Eds.), an Lguide publication, http://www.lguide.com/ reports/, 2001.

Zuboff, S. In the Age of the Smart Machine: The Future of Work and Power, New York: Basic Books, 1998. 


\section{APPENDIX A}

Table 1A. Overview of semi-structured interview questions used in the study

\begin{tabular}{|c|c|c|}
\hline Research Question & Semi-Structured Interview Questions & Interviewees \\
\hline $\begin{array}{l}\text { What are the roles of } \\
\text { the Learning } \\
\text { Management System } \\
\text { in managing learning } \\
\text { within the } \\
\text { organization? }\end{array}$ & $\begin{array}{l}\text { Does LMS support training administration? } \\
\text { Does LMS support diverse learners \& diverse learning } \\
\text { contexts? } \\
\text { Does LMS facilitate competence development to meet } \\
\text { particular business objectives? } \\
\text { Does LMS enable cohesive learning throughout } \\
\text { enterprise? } \\
\text { Does LMS encourage employee accountability for } \\
\text { learning? } \\
\text { Does LMS enable monitoring and analysis of 'learning } \\
\text { condition' within the organization? } \\
\text { What are the other key roles or attributes of the LMS? }\end{array}$ & $\begin{array}{l}\text { HR Training \& } \\
\text { Dev. Manager / } \\
\text { LMS Manager } \\
\text { (Irish Operation) } \\
\text { HR Manager } \\
\text { (Irish Operation) } \\
\text { Technical } \\
\text { Training } \\
\text { Specialist } \\
\text { (Manufacturing } \\
\text { Organization. }\end{array}$ \\
\hline $\begin{array}{l}\text { What is the } \\
\text { relationship between } \\
\text { the Learning } \\
\text { Management System } \\
\text { and other IS that } \\
\text { support learning in } \\
\text { the organization? }\end{array}$ & $\begin{array}{l}\text { What types of learning/training environments are used in } \\
\text { CEM and how does the LMS incorporate them? } \\
\text { What Knowledge Management Systems are in use in } \\
\text { CEM and how does the LMS incorporate them? } \\
\text { What Content Management Systems are in use in CEM } \\
\text { and what functionality do they provide to the LMS? } \\
\text { Is there any relationship between the LMS and other } \\
\text { Information Systems that support ad hoc/informal } \\
\text { learning? }\end{array}$ & $\begin{array}{l}\text { EMEA) } \\
\text { Technical } \\
\text { Operations } \\
\text { Manager } \\
\text { (Customer } \\
\text { Services } \\
\text { Organization, } \\
\text { EMEA) }\end{array}$ \\
\hline $\begin{array}{l}\text { What theories have } \\
\text { influenced how the } \\
\text { organization uses the } \\
\text { Learning } \\
\text { Management System } \\
\text { to manage learning } \\
\text { within the } \\
\text { organization? }\end{array}$ & $\begin{array}{l}\text { Does CEM seek to manage work competencies using the } \\
\text { LMS? } \\
\text { Does CEM seek to manage the competency chain using } \\
\text { the LMS? (i.e. planning, acquisition, development and } \\
\text { utilization of competencies) } \\
\text { Does CEM seek to manage its human capital using the } \\
\text { LMS? (i.e. knowledge, innovativeness, company values) } \\
\text { Does CEM seek to manage its structural capital using the } \\
\text { LMS? (i.e. external customer and supplier relationships, } \\
\text { internal innovation and process capital) } \\
\text { Does CEM seek to manage knowledge using the LMS? } \\
\text { (from a technology perspective or a people perspective) } \\
\text { Does CEM seek to transfer/convert knowledge using the } \\
\text { LMS? (if so, what forms of conversions are supported) } \\
\text { Does CEM seek to support the three key learning models } \\
\text { using the LMS? (learn facts/rules, apply } \\
\text { concepts/procedures, analysis/exploration) } \\
\text { Does CEM seek to support the three types of } \\
\text { organizational learning using the LMS? (changes in } \\
\text { rules/processes, changes in strategy/assumptions, changes } \\
\text { in the way strategy/assumptions are generated) }\end{array}$ & $\begin{array}{l}\text { Training } \\
\text { Specialist } \\
\text { (Customer } \\
\text { Services } \\
\text { Organization, } \\
\text { EMEA) } \\
\text { Training \& } \\
\text { Knowledge } \\
\text { Management } \\
\text { Specialist } \\
\text { (Customer } \\
\text { Services } \\
\text { Organization, } \\
\text { EMEA) } \\
\text { Global } \\
\text { Technical } \\
\text { Support Training } \\
\text { Manager } \\
\text { (Customer } \\
\text { Services } \\
\text { Organization, } \\
\text { Asia Pacific) }\end{array}$ \\
\hline
\end{tabular}




\begin{tabular}{|c|c|c|}
\hline Research Question & Semi-Structured Interview Questions & Interviewees \\
\hline & $\begin{array}{l}\text { Does CEM seek to support the three levels of } \\
\text { organizational learning using the LMS? (individual, } \\
\text { group, organizational) } \\
\text { Does EMD seek to support the four primary } \\
\text { organizational learning processes using the LMS? } \\
\text { (acquire knowledge, distribute information, information } \\
\text { interpretation, organizational memory) } \\
\text { Is CEM's approach to managing learning using the LMS } \\
\text { more influenced by organizational Learning Management } \\
\text { or Knowledge Management (building learning/mining } \\
\text { knowledge, learning as process/knowledge as resource, } \\
\text { focus on people and community/knowledge distribution } \\
\text { and cognition, organizational projects/lT projects, } \\
\text { system/resource based view) }\end{array}$ & $\begin{array}{l}\text { Software } \\
\text { Engineer } \\
\text { (Software } \\
\text { Engineering } \\
\text { Organization, } \\
\text { EMEA) }\end{array}$ \\
\hline
\end{tabular}

